\title{
The Unreasonableness of Coerced Cooperation: A Comment upon the NCAA Decision's Rejection of the Chicago School
}

James F. Ponsoldt

University of Georgia School of Law, ponsoldt@uga.edu

b

\section{Repository Citation}

James F. Ponsoldt, The Unreasonableness of Coerced Cooperation: A Comment upon the NCAA Decision's Rejection of the Chicago School (1986),

Available at: https://digitalcommons.law.uga.edu/fac_artchop/525

This Article is brought to you for free and open access by the Faculty Scholarship at Digital Commons @ University of Georgia School of Law. It has been accepted for inclusion in Scholarly Works by an authorized administrator of Digital Commons @ University of Georgia School of Law. Please share how you have benefited from this access For more information, please contact tstriepe@uga.edu. 


\section{The unreasonableness of coerced cooperation: a comment upon the $N C A A$ decision's rejection of the Chicago school}

BY JAMES F. PONSOLDT*

\section{Introduction}

The Supreme Court's decision in the $N C A A$ case, ${ }^{1}$ holding that the NCAA's mandatory rules controlling the exclusive sale of television rights to intercollegiate football violate section 1 of the

* Associate Professor of Law, University of Georgia School of Law. The author was of counsel to the respondents in National Collegiate Athletic Association v. Board of Regents of the University of Oklahoma.

AUTHOR'S NOTE: The author expresses appreciation for the research assistance of Jesse Barrow, J.D. 1985, University of Georgia School of Law.

1 Board of Regents of the University of Oklahoma and the University of Georgia Athletic Association v. National Collegiate Athletic Association, 546 F. Supp. 1276 (D.C.W.D. Okla. 1982), aff'd, 707 F.2d 1147 (10th Cir. 1983), aff'd sub nom. National Collegiate Athletic Association v. Board of Regents of the University of Oklahoma, 104 S. Ct. 2948 (1984).

(c) 1987 by Federal Legal Publications, Inc. 
Sherman Antitrust Act, ${ }^{2}$ is important for several reasons. First, it is among but a few decisions to hold that a restraint of trade although not per se illegal $^{3}$ is economically unreasonable under the rule of reason. Second, its implied questions about the goals and relevance of antitrust enforcement coincide with questions about the governmental regulation of business now addressed in law reviews, editorial pages, and by congressional committees. ${ }^{4}$ Last, it may resolve warring antitrust ideologies and reaffirm economic freedom as an enforcement goal.

$2 \quad 15$ U.S.C. $\S 1$ (1976) provides, in relevant part: "Every contract, combination in the form of trust or otherwise, in restraint of trade or commerce among the several states, or with foreign nations, is declared to be illegal. ...."

$3 \quad$ See, e.g., Lipner, Antitrust's Per Se Rule: Reports of Its Death Are Greatly Exaggerated, 60 Denver L.J. 593 (1983). One of the most often cited descriptions of the per se rule was written by Justice Black in Northern Pac. Ry. Co. v. United States, 356 U.S. 1 (1958). "However, there are certain agreements or practices which because of their pernicious effect on competition and lack of any redeeming virtue are conclusively presumed to be unreasonable and therefore illegal without elaborate inquiry as to the precise harm they have caused or the business excuse for their use. This principle of per se unreasonableness not only makes the type of restraints which are proscribed by the Sherman Act more certain to the benefit of everyone concerned, but it also avoids the necessity for an incredibly complicated and prolonged economic investigation into the entire history of the industry involved, as well as related industries, in an effort to determine at large whether a particular restraint has been unreasonable-an inquiry so often wholly fruitless when undertaken. Among the practices which the courts have heretofore deemed to be unlawful in and of themselves are price fixing, division of markets, group boycotts, and tying arrangements." 356 U.S. at 5 (citations omitted).

4 Compare Lester Thurow, Let's Abolish the Antitrust Laws, New York Times Business Section, October 19, 1980, with Reader Comment, New York Times Business Section, November 2, 1980; compare Fred Smith, Why Not Abolish Antitrust?, Regulation, Jan.-Feb. 1983, with Reader Comment, Regulation, May-June, 1983; compare Ernest Gellhorn's editorial regarding the tenure of William Baxter as chief antitrust enforcer, Wall Street Journal Editorial Page, January 6, 1984, 
The NCAA's Chicago school defense is premised on the idea that government should normally defer to the presumptively efficient decisions of business, especially those that enhance economic integration and cooperation. Because of private economic coercion in the marketplace and economic rivalry in our political system, this idea is flawed. Fortunately, the $N C A A$ decision reaffirms that the Sherman Act was enacted to prohibit the private exercise of economic coercion that undermines economic freedom and diminishes market rivalry. ${ }^{5}$

with Reader Comment, Wall Street Journal Editorial Page, January 27, 1984; compare Ponsoldt, Antitrust: When Law Clashes With a Truth, New York Times Editorial Page, January 3, 1984, with Eizenstat, $A$ New Antitrust Law, New York Times Editorial Page, April 22, 1984; compare Ponsoldt, Reagan's Anti-Regulatory Stand Politicizes Policy on Mergers, New York Times Editorial Page, October 13, 1983, with James C. Miller, 3rd, The Proper Question in Adjudicating a Merger, New York Times Editorial Page, October 23, 1983.

See, most recently, H. 2735, approved by the House Committee on the Judiciary on June 14,1985, which would establish stricter standards for the approval of business mergers, and the accompanying subcommittee record. As examples of the academic debate, compare Landes \& Posner, Market Power in Antitrust Cases, 94 HaRv. L. Rev. 937 (1981), with Sullivan, Antitrust, Microeconomics, and Politics: Reflections on Some Recent Relationships, 68 CALIF. L. Rev. 1 (1980). See also Ponsoldt, Reagan Circuit Judges Assault the Rule of Law, National Law Journal Editorial Page, February 7, 1983, quoted in Shafer v. Bulk Petroleum Corp., 569 F. Supp. 621, 625-26, n.4 (E.D. Wis. 1983).

5 The alleged choice between economic freedom and regulatory order was poorly framed from the beginning. Unregulated private conduct can curtail freedom and achieve a kind of "order" to a greater degree than can democratically imposed government regulation. The correctly identified political choice is not between freedom (nonintervention by government) and order (government regulation), as the Reagan enforcement policies and economic theory have implied, but rather between concentrations of power not responsive to citizen control, whether public or private, and a legitimately functioning democracy with sufficient public regulation to check private trusts (whether corporate, financial, or labor union) and sufficient internal control to avoid bureaucratic tyranny. The $N C A A$ decision confirms that the Sherman Act was designed to promote freedom from private abuses of power. 
Thus, the Supreme Court has rejected Chicago's ideological vision for a historical and pragmatic approach that polices business conduct to preserve our competitive free market system, regardless of the short-term efficiency considerations. ${ }^{6}$

\section{Conflicting theories of antitrust}

Much of the ideological debate over section 1 of the Sherman Act can be traced to disagreement over legislative purposes. ${ }^{7}$ The historical side of the debate sees the law protecting the competi-

6 "Broadcast Music squarely holds that a joint selling arrangement may be so efficient that it will increase sellers' aggregate output and thus be procompetitive. See 441 U.S. at 18-23." NCAA, 104 S. Ct. at 2961. The alleged direct relationship between "efficiency" and "competition" has not always been recognized by the Court. In fact, Justice Frankfurter squarely acknowledged that, at least in the short run, activities which promote efficiency can be anticompetitive, and vice versa, particularly when the conduct which results in cost savings at the same time creates market power, so that the efficient producer does not have to respond to the commands of a competitive market. See Standard Oil Co. of California (Standard Stations) v. United States, 337 U.S. 293, 309, 312 (1949). See also the concurring opinion by Douglas: "The economic theories which the Court has read into the Antitrust Laws have favored rather than discouraged monopoly. . . "337 U.S. at 315.

7 Professor Sullivan reviews two basic schools of thought, one he calls the "Chicago" school, characterized by the use of only two "static, structural models, the competitive market and the monopolized market" to analyze industry performance. Sullivan contends that the Chicago school relies on cartel and monopoly theory only to explain the occurrence of noncompetitive performance. The school sees monopoly as extremely rare and, since it recognizes few entry barriers, believes cartels are extremely unstable. Sullivan closes his description of the Chicago school with the sarcastic observation: "Chicago theory makes for an attractively tidy antitrust world. Because private markets work surpassingly well so long as government does not interfere with them, and because most apparent aberrations turn out upon analysis to reflect efficiency-producing decisions by traders operating under the constraints of competitive pressure, the antitrust policemen need not be exceedingly busy. It is necessary to keep a sharp eye out for cartels, of course, for, though cartels are always under pressure and soon fall 
tive market system by guaranteeing free and easy market entry, by stimulating potential rivalry, and by dispersing private power. ${ }^{8}$ Chicago contends that wealth maximization is the exclusive anti-

apart, they may do some harm before that inevitable end. Thus, there is some socially efficient level of investment in antitrust enforcement. All that remains is for Congress to work out an efficient matrix of deterrents and for enforcement agencies to direct their activities solely toward those violations that Chicago school theory identifies as socially harmful." Sullivan, Economics and More Humanistic Disciplines: What Are the Sources of Wisdom for Antitrust?, 125 U. PA. L. REv. 1214, 1216-18 (1977).

Sullivan characterizes the main competing tradition, which he calls the "Harvard" school, as "proposing more complex and realistic models, even at the cost of less theoretical solutions." He states the so-called Harvard school is less likely to excuse oligopolistic industry structure on the ground of scale efficiency and more likely to recognize a variety of entry barriers. The school recognizes the possibility of interdependent pricing in oligopolistic markets and sees ways in which tying arrangements, requirements contracts, or vertical mergers can harm competition. Id.

Professor (now Judge) Richard Posner, whom Sullivan identifies as a member of the so-called Chicago school, responded that it is no longer "a simple thing to identify a Harvard or a Chicago position on issues of antitrust policy." He attributes this to "the maturing of economics as a social science and as a corollary thereto, the waning of the sort of industrial organization that provided the intellectual foundations of the Harvard school." With its intellectual foundation withered away, according to Posner, the two schools have joined on a variety of issues. Posner, The Chicago School of Antitrust Analysis, 127 U. PA. L. Rev. 925 (1979).

8 L. Sullivan, Handbook of the LaW of Antitrust $\S 5$ (1977). Sullivan comments in his treatise that the antitrust laws came out of a "rough-hewn" populist tradition which saw wrong and right in "Dickensian clarity" and mistrusted large institutions and "lords of commerce." He states that later, more sophisticated rationales emerged.

For one thing, competition kept private markets working toward efficient resource allocation, efficient production methods, and efficient methods of distribution. Here competition was a stick. The businessman who was inefficient would lose out to his competitors.

Second, competition was seen as breaking up concentrations of economic power which were dangerous in themselves, in the view of 
trust goal, thereby limiting the concept of "competition." It regards efficiency the polestar of rational Sherman Act solutions. ${ }^{9}$

some. This meant there was less need for government intervention with the attendant danger of loss of personal liberty.

Finally, competitive markets were seen as facilitating entry at the smallest efficient scale and thereby promoting the goal of economic opportunity. Id. Interestingly, this last justification finds historical support in the English common-law tradition of refusing to enforce contracts which would disable a person from plying his or her lawful trade and hence becoming dead weight on society. This justification was recognized by Circuit Judge Taft in United States v. Addyston Pipe \& Steel Co., 85 F. 271 (6th Cir. 1898), aff'd, 175 U.S. 211 (1899). Presumably, English judges did not buy the theory that the person to whom the right of contract was bargained was inherently more efficient at plying the trade than the person who gave up the trade and that the person who gave up the trade should therefore pursue some other line of work which would, of course, be a more efficient use of labor. Addyston, supra.

9 As noted above, an important member of this school of thought is Judge Richard Posner of the Seventh U.S. Circuit Court of Appeals, who argues that economic efficiency should be the only goal of the antitrust laws. He rejects sociopolitical arguments and interpretations of the act. The argument that monopoly structure transfers consumer wealth to the stockholders of monopolistic firms is, Posner argues, incorrect because competition to obtain and hold monopoly status will transfer expected monopoly gains into social costs and hence put the gains back into society. The argument that economic concentration facilitates industry manipulation of the political process to obtain special legislation which will give the monopolist an inordinate or unfair amount of protection is belied by the fact that many unconcentrated industries-farming, local broadcasting, trucking, banking, and medicine-enjoy governmental protection against competition in the form of barriers to entry, restrictions on advertising, etc. The argument that the Sherman Act was designed to protect small business fails, in Posner's mind, because antitrust laws should not protect small businesses at the expense of the consumer by allowing them to act inefficiently. Hence, Posner concludes that efficiency is the sole appropriate goal of the antitrust laws. R. Posner, Antitrust Law 3-21 (1976).

Posner's comments in this regard have been criticized on several grounds. Among the criticisms is, first, that simply because, as Posner argues (id. at 8-22), Congress recognized the "propensities" of monopolies to raise prices by restricting output, it does not necessarily follow that the proponents of the Sherman Act were concerned with the 
Sometimes the two sides reach similar conclusions. For example, both would condemn market division agreements among competitors. ${ }^{10}$ But the two would disagree over industrial deconcentration. The Chicago school would find data that industry, due to economies of scale and other economic factors, can support few large competitors, and thus would de-emphasize the importance of concentration.

The historical approach views antitrust as both political and economic, ${ }^{11}$ something more than allocative efficiency. ${ }^{12}$ It encour-

modern notion of "economic efficiency." When the act was passed, the economic models which support this philosophy were just being developed and hence were not available to the authors of the bill. Second, he has been criticized for completely ignoring the goal of "diffusion and decentralization of power as an end in itself." It is not hard to infer such intent from Sherman Act coauthor Edmund's allusions to trusts as "grinding tyrannies" and Senator Haar's complaint that the "great monopolies . . . are a menace to republican institutions." Scherer, The Posnerian Harvest: Separating Wheat From Chaff, 86 YALE L.J. 974, 977, 980 (1977) (book review of ANTITRUST LAw).

10 Bork, The Rule of Reason and the Per Se Concept: Price Fixing and Market Division, 75 YALE L.J. 373, 384 (1966). In this case there would be no integration of functions related to marketing a product. The testing laboratory is not logically related to the market division. Hence there is no potential economic efficiency created by the market division.

11 See, e.g., Sullivan, Antitrust, Microeconomics, and Politics: Reflections on Some Recent Relationships, 68 Calif. L. Rev. 1, 4 (1980). Professor Sullivan describes this approach as "eclectic." He identifies this tradition with many of the Warren Court's decisions.

Characteristic goals of this school include preservation of an industrial structure composed "of large numbers of small competitors as an end in itself." The Supreme Court, using this theory, has embraced a "multivalued antitrust tradition" in which the concept of competition served political and social objectives of twentieth-century liberalism. The Court sought "easy market access for small businesses, protection of dealer independence, and correction of wide disparity in bargaining power." It also sought to assure that price and cost were closely related. Id.

12 See, e.g., H. Thorelli, The Federal Antitrust Policy (1955). See also Blake \& Jones, Toward a Three Dimensional Antitrust Policy, 
ages rivalry to spur producers to greater effort, ${ }^{13}$ and it prefers decentralized power ${ }^{14}$ and small economic units. For Professor Sullivan the Sherman Act is a "response to" and "mediator of the profound changes in technology and industrial structure that have accrued in America over the course of the present century." Chicago's neoclassicism fails to account for the "non-material and less readily quantifiable welfare consequences of change in technology and industrial structure." While economics should play a role, case law must be supplemented by "something more than economics" that Sullivan argues would include "social and political values which are important components of anti-trust not recognized by the neo-classical economics of the Chicago School." 15

Others in the historical camp argue that the Sherman Act did not result from "a consensus among economists as to its utility in enhancing economic efficiency, but a rough consensus in society at large as to its value in curbing the dangers of excessive market power . . . [I]t is based on a political and moral judgment rather than economic measurement or even distinctively economic crite-

65 Colum. L. Rev. 422, 423-24 (1965). Blake and Jones argue that the goals of antitrust include preservation of "self-policing markets" and "protection of individuals from oppression and foreclosure of opportunities by economically powerful interests," and that these goals may be found in both the legislative history of the Sherman Act and the early decisions and were not "smuggled into the law illicitly, under cover of darkness," during the 1950s and 1960s. For a further discussion of this topic, see Dewey, Competitive Policy and National Goals: The Doubtful Relevance of Antitrust, in Perspectives on ANTITrust 63, 85-87 (A. Phillips ed. 1965) (arguing that antitrust cannot really be justified on economic grounds, but must be based on policies "which seek to shake the mighty in their seats" and protection of small producers).

13 This was the reasoning of Justice Clark's dissent in White Motor Co. v. United States, 372 U.S. 253 (1963).

14 See L. Sullivan, supra note 8, at 11.

15 Sullivan, supra note 7. This should not be read, however, to foreclose allocative efficiency as a goal of antitrust. These theorists simply believe efficiency is not the only goal. 
ria." ${ }^{16}$ Sociologist Charles Lindblom argues that liberty depends on competition and that markets like political systems must be decentralized and diffused of influence and power, with mutual adjustments so that individuals and small groups are free to strive. ${ }^{17}$

Moreover, the Supreme Court has argued in Brown Shoe Co. $v$. United States that Congress was concerned with the accumulation of great wealth and power in the hands of a few:

The debates show that doubt as to whether there was a common law of the United States which governed the subject in the absence of legislation was among the influences leading to the passage of the act. They conclusively show, however, that the main cause which led to the legislation was the thought that it was required by the economic conditions of the times, that is the vast accumulation of wealth in the hands of corporations and individuals, the enormous development of corporate organization, the facility for combination which such organizations afforded, the fact that the facility was being used and that combinations known as trusts were being multiplied and the widespread impression that their power had been and would be executed to oppress individuals and injure the public generally. ${ }^{18}$

There is no mention of economic efficiency or wealth maximization, but an instinctive mistrust of concentrated economic power and a fear of individuals "oppressed" by wealth and power.

The Chicago school sees wealth maximization through economic efficiency as the rational antitrust goal, ${ }^{19}$ if not the

16 R. Hofstadter, What Happened to the Antitrust Movement?, in The Paranoid Style in American Politics and Other Essays 232-34 (1965) (the author also reviews other works which make the same argument).

17 C. Lindblom, Politics and Markets 49, 165 (1977).

18 See, e.g., Standard Oil Co. v. United States, 221 U.S. 1, 51 (1910).

19 For instance, Bork and Bowman argue that antitrust law too often protects inefficient producers from their competitive rivals. Bork \& Bowman, The Crisis in Antitrust, 65 Colum. L. Rev. 363 (1965). See also supra note 10. 
absolutely authentic, legislatively historical goal. ${ }^{20}$ It argues that judges must shape statutes and histories to wealth maximization and efficiency. Robert Bork, for example, interprets competition as "a shorthand expression designating any state of affairs in which consumer welfare cannot be increased by moving to an alternative state of affairs through judicial decree." As defined, his version of competition includes such things as low prices, innovation, and product choice, ${ }^{21}$ but not rivalry, an absence of restraint, an inability to influence price through purchase or sale, or dispersed ownership of production. Congress did have these other things in mind in 1890, and if "our society is founded upon the elimination of rivalry . . . , Bork is probably correct that some cooperation and integration are necessary to achieve efficient production, but only within a larger core of democratic liberties that Americans prefer to efficiency.

Bork dismisses the threat of market concentration, and argues that the Brown Shoe term "fragmented" is unclear and "without much content." He also rejects the relevance of competition to locally owned businesses, ${ }^{22}$ and argues that Congress' motives are impossible to divine.

One frequently hears talk of the original meaning of the Sherman Act of the intent of Congress in enacting that law, but it can hardly be stressed too much that with respect to the Sherman Act, . . . such talk of legislative intention is more than usually foolish. Congress

20 Bork, The Rule of Reason and the Per Se Concept: Price Fixing and Market Division, 74 YALE L.J. 775, 783 (1965).

21 Id. at 833. Bork argues that wealth maximization is a more appropriate goal than the vindication of various political and social goals because the courts need only make economic distinctions which are firmly rooted in "economic reality." He continues that the policy of wealth maximization is better suited to the "scope, nature and ease of administration of the law, that the job of choosing what social values should be protected should be with the legislature and that the 'wealth maximization' standard creates certainty." R. Bork, THE ANTITRUST Paradox 61 (1978).

22 R. Bork, supra note 21 , at 60. 
simply had no discoverable intention that would help a court decide a case one way or another. ${ }^{23}$

Elsewhere, though, Bork finds the legislative record surprisingly luminous, especially the isolated comments of Senator Sherman about the act not interfering with efficiency. To advance his consumer welfare thesis, ${ }^{24}$ Bork eschews the rigorous interpretive constancy he yearns for the courts to adopt. He bases law, efficiency, and his consumer welfare idea on an extremely fragile interpretive methodology.

The two schools also compete to determine the basis of section 1 liability under a rule of per se illegality or a rule of reason. ${ }^{25}$ The per se rule, justified by concerns of judicial effi-

\section{Bork, supra note 20.}

24 Bork, Legislative Intent and Policy of the Sherman Act, 9 J.L. \& ECON. 7, 27 (1966).

25 See supra note 3 and infra note 26 and accompanying text. The rule of reason condemns restraints that are more restrictive than reasonably necessary to promote a procompetitive objective. Thus, the rule of reason requires the court to analyze the ambiguous motives underlying the conduct complained of, and the economic effects thereof, to determine whether the conduct is primarily anticompetitive or procompetitive. See Continental T.V., Inc. v. GTE Sylvania, 433 U.S. 36, 57-60 (1977); Chicago Bd. of Trade v. United States, 246 U.S. 231, 234 (1918). See generally Zelek, Stern \& Dunfee, A Rule of Reason Decision Model After Sylvania, 68 CALIf. L. Rev. 13 (1980); Comment, Applying the Rule of Reason: $A$ Survey of Recent Cases and Comment, 17 SAN Diego L. Rev. 335 (1980).

As a general matter, except for the $N C A A$ decision, and the more recent decision, consistent with $N C A A$, in FTC v. Indiana Federation of Dentists, 106 S. Ct. 2009 (1986), the Court has applied an "all or nothing" approach to section 1 analysis: either the challenged conduct is per se illegal or the per se rule does not apply and the conduct is not unreasonable.

Compare Monsanto Co. v. Spray-Rite Service Corp., $104 \mathrm{~S}$. Ct. 1464 (1984), Arizona v. Maricopa County Medical Society, 457 U.S. 332 (1982), Catalano, Inc. v. Target Sales, Inc., 446 U.S. 643 (1980), and National Society of Professional Engineers v. United States, 435 U.S. 679 (1978) (condemning allegedly reasonable conduct under the per se rule), with Northwest Wholesale Stationers, Inc. v. Pacific Stationery \& 
ciency, predictability, and certainty, ${ }^{26}$ prohibits presumptively anticompetitive conduct outright. The Chicago school, because of its abhorrence of government and preference for private action, would not prohibit any conduct outright because efficiency can result from diminished rivalry. Therefore, conduct that diminished competition could never be characterized as an illegal restraint of trade without a rule of reason inquiry into possible efficiencies. ${ }^{27}$ Even cooperation among producers to stabilize prices by restricting output, if integrated into a marketing structure that more efficiently sold product through eliminated transaction costs, should be lawful-as the NCAA contended. ${ }^{28}$

The conflict between the two schools first reflected itself in the history of the Supreme Court's price-fixing cases. In United States $v$. Trenton Potteries, ${ }^{29}$ the Court invalidated a price-fixing

Printing Co., 105 S. Ct. 2613 (1985), Broadcast Music, Inc. v. Columbia Broadcasting System, Inc., 441 U.S. 1 (1979), and Continental T.V., Inc. v. GTE Sylvania, 433 U.S. 36 (1977) (refusing to apply per se rule and suggesting that challenged conduct was not economically unreasonable).

26 Indeed, some commentators have declared that the rule of reason, without the per se rule, is completely ineffective as an antitrust enforcement tool. See, e.g., Brodley, The Legal Status of Joint Ventures Under the Antitrust Laws: A Summary Assessment, 21 ANTITRust Bull. 453, 464 (1976): "The rule of reason, calling as it does for a consideration of all facts or to exaggerate only slightly, all evidence that either party thinks relevant-is to be blunt an ineffective tool for antitrust enforcement."

27 Note, Fixing the Price Fixing Confusion: A Rule of Reason Approach, 92 YALE L.J. 706, 714 (1983). The author argues that since a practice cannot be said to be price-fixing unless it has an anticompetitive effect, a court must always examine the competitive effect of the challenged conduct. "As a result, the distinction between characterizing a practice as price fixing and determining its purpose and effect and hence the distinction between the per se rule and rule of reason cannot ultimately be maintained."

28 Frank Easterbrook has written that "under NCAA the defendant may offer an economic justification even of a naked restraint." Easterbrook, The Limits of Antitrust, 63 Tex. L. Rev. 1, 13 (1984). 
scheme and rejected the defendants' argument that the prices established were "reasonable." A similar argument was rejected by Justice Douglas, in United States $v$. Socony-Vacuum Oil,,$^{30}$ who held efficiency defenses antithetical to the Sherman Act. ${ }^{31}$ However, the Court has upheld the efficiencies of voluntary participation that reduce transaction costs through orderly marketing. ${ }^{32}$

Today, in evaluating private combinations, the Supreme Court may find their coerciveness to be decisive. ${ }^{33}$ Indeed, the basic disagreement in $N C A A$ was over the efficiencies of cooperation and integration achieved through coercion. An agreement that limits the output of collegiate football broadcasts through a coercion that limits rivalry should not be justifiable as an economically efficient marketing arrangement. ${ }^{34}$

30310 U.S. 150 (1940) (prosecution of oil companies for buying up surplus oil to keep the price of oil high).

31 "Ruinous competition, financial disaster, evils of price cutting and the like appear throughout our history as ostensible justifications for price-fixing. If the so-called competitive abuses were to be appraised here, the reasonableness of prices would necessarily become an issue in every price fixing case. In that event the Sherman Act would soon be emasculated. . . . It would not be the charter of freedom which its framers intended." Id. at 221. This is basically the efficiency argument, since the producers were arguing that they would not be able to operate without the price restraints. Id.

32 "[A] bulk license of some type is a necessary consequence of the integration necessary to achieve these efficiencies and a necessary consequence of an aggregate license is that its price must be established." Id. at 21.

33 See, e.g., Ponsoldt, The Application of Sherman Act Antiboycott Law to Industry Self-Regulation: An Analysis Integrating Nonboycott Sherman Act Principles, 55 S. CAL. L. Rev. 1, 15-30 (1981) (arguing that intent has been important in determining whether concerted action violates antitrust laws).

34 See infra notes 143-159 and accompanying text. 


\section{Background of the NCAA case}

The NCAA is a voluntary nonprofit association organized in 1905 to promote and preserve amateurism in intercollegiate athletics as a vital and integral part of higher education. The NCAA has 752 colleges and universities, plus allied member conferences and associated and affiliated members, each having single voting rights. The membership elects a 22 -member council to establish and direct general policy.

NCAA legislation authorizes it to control both televising football and the television contracts themselves. This authority was exercised for one-, two-, and four-year terms over 30 years with periodic membership approval. The NCAA's annual $\$ 23$ million budget was financed mainly by the sale of basketball tournament telecast rights, and by membership fees and an assessment on football television revenues. The NCAA implements member action through committees, including a Football Television Committee.

The NCAA complaint was brought by a member institution and an athletic association that conducts the intercollegiate athletic program of a member institution. The University of Oklahoma and the University of Georgia Athletic Association contended that the NCAA had violated the antitrust laws and deprived them of their lawful property rights by the dealings of its Television Committee over the last 30 years. Plaintiffs sought a declaratory judgment that the television contracts between the NCAA and the networks were illegal and an injunction generally prohibiting the NCAA from its continued reign over its members' television rights. ${ }^{35}$

35 Although plaintiffs dropped their request for class certification, the action was financed in part by the College Football Association (CFA). The CFA was formed in 1977 by most of the dominant footballplaying colleges-including the members of the Atlantic Coast Conference, the Big Eight Conference, Southeastern Conference, and the Western Athletic Conference, plus the major independents such as Notre Dame, Pittsburgh, and Penn State. The only comparable institutions which have not joined the CFA are the 20 members of the Big Ten 


\section{Plaintiffs' factual contentions}

The plaintiffs' complaint focused on the restraint of their economic freedom through coerced cooperation in the sale of television football rights. As a condition to membership, all universities were required to submit their television broadcast rights to the NCAA, pursuant to the authority of its constitutional provision that "televising of intercollegiate football games of member institutions shall be controlled by bylaws enacted by the Association." The NCAA, as exclusive bargaining agent for its members, except for limited "exception telecasts" with its approval, negotiated with the networks to sell all members' contractual television rights at a "minimum aggregate fee," i.e., a fixed floor under the total compensation received by members for their television rights in the seasons covered by the contract. ${ }^{36}$ The contracts specified the total number of games televised in any season, and the maximum number of games that a university could televise. While the 1982-1985 contracts added CBS and the Turner Cable Broadcasting System, ${ }^{37}$ the "new" NCAA plan

and Pacific-10 Conferences. The CFA was formed to give its members a stronger voice in asserting their interests within the NCAA, and the CFA itself is an affiliate member of the NCAA.

36 The NCAA historically made "recommendations" to the contracting network regarding the precise amount to be paid each university selling its television broadcasting rights under the contract. These recommendations were implemented by the contracting network and eliminated negotiation of the rights fee altogether. The rights fee recommended by the NCAA, and paid by the contracting network, was derived by a formula and was always the same for each contracting university operating under NCAA controls. See generally 546 F. Supp. at 1276 et seq. See also, for the following summary of plaintiffs' position, Respondents' Response to Application for a Stay, submitted to the Supreme Court in S. Ct. No. A-24 on July 19, 1983.

37 The NCAA was very active in 1981-82, not only in rearranging its television controls, but in assuring that no doubt was left as to its assumption of absolute control over its members' television rights. The NCAA adopted an "official interpretation" of its bylaws, stating that "[t]he Association shall control all forms of televising of the intercollegiate football games of member institutions during the traditional 
operated as before; the networks eliminated competition between themselves for individual games, giving a single network absolute market control over specific games.

The complaint also alleged that a member's attempt to market television rights independent of the NCAA met a myriad "of NCAA sanctions, ranging from reprimand to expulsion . . . ," as when the NCAA threatened plans of the College Football Association to televise football. The threatened sanctions effectively deprived the members of "a fully rounded intercollegiate athletic program." 38

\section{The defense summarized}

The NCAA contended that its controls and network contracts were reasonable. The controls protected gate attendance that might otherwise be injured or destroyed by television. A study by the NCAA's Television Committee and a report by the National Opinion Research Center of the University of Chicago, as well as follow-up studies, analyses, and reports, showed that uncontrolled television substantially affected gate attendance. ${ }^{39}$

football season. . . . Any commitment by a member institution with respect to the televising or cablecasting of its football games in future seasons necessarily would be subject to the terms of the NCAA football television plan applicable to such season." Similarly, the NCAA amended its constitution in 1982 to provide that all "telecasting, cablecasting or otherwise televising of intercollegiate football games of member institutions shall be controlled by bylaws enacted by the Association." The NCAA was quick to implement this clarification of its absolute authority by threatening members of the CFA, who were attempting to market a television package of their own, with the full panoply of NCAA sanctions (including expulsion) should the CFA members go through with their plan. The plan was therefore abandoned.

38 The NCAA also is active in regulating sports activities of its members other than football, but football is the only sport in which the NCAA has taken unto itself the power to regulate the televising of college athletic events.

39 These conclusions were presented to the entire membership which approved a procedure which has evolved over the years whereby the 
Over the last 30 years, more than 90 percent of the membership, voting for the principles of negotiation or the television plan, favored the plan. The three main television networks held television rights at different times. $\mathrm{ABC}$ held the contract from 1978 through 1981, but from 1982 through 1985 there were contracts with $\mathrm{ABC}$ and $\mathrm{CBS}$, after extensive negotiations with all three. ${ }^{40}$

The NCAA's television contracts provided that the network would select the games to be televised and would negotiate the rights and fees with the host college under a specific game contract for a particular game. The "only" restrictions were that the contract must be with the network under contract with the NCAA and must contain terms consistent with the current NCAA television plan. The host college was free to refuse the sale of its television rights, and had the freedom to negotiate a price for its rights. However, the NCAA suggested to the network a formula for differentiating between the fees for national and regional telecasts, and occasionally suggested individual game

Television Committee would hold hearings to gather all pertinent information, submit a questionnaire to all the members to ascertain their views, prepare detailed principles of negotiation consistent therewith, and submit the principles of negotiation to the council and then to the membership for a referendum vote. After a favorable vote, the Television Committee would negotiate with the various networks and make one or more contracts on the best available terms, subject to the approval of the council. The Television Committee also would formulate the football television plan which was approved by the council. Both the contracts and the football television plan were consistent with the principles of negotiation approved by the membership.

40 These contracts provided for a series of college games to be televised on Saturday afternoons during the fall season, some of which were nationally televised, whereas others were regionally televised. They provided for annual minimum aggregate compensation to be paid by each network for the rights to televise the NCAA series games. For 1982 , the aggregate rights fees to be paid by each network totaled at least $\$ 29,500,000$, and could have exceeded that sum. Subtracted from that sum, however, was an assessment to be paid to the NCAA and rights fees for certain Division I-AA, II, and III NCAA football championships and regular season games. 
fees. In every instance, the rights fee paid for each game was established by the network, subject to agreement by the host college and the consent of the visiting institution. ${ }^{41}$

The NCAA argued that a college's right to negotiate its own prices was unimpaired. If a college chose to accept what a network offered, without negotiating or bargaining, the price was not a combination or conspiracy between the network and the NCAA. The NCAA/network contracts merely ensured minimum aggregate compensation for committing exclusive future rights to televise a series of NCAA members' games; they did not provide a maximum price or ceiling or in any way restrain the price a college could negotiate. It also argued that the minimum aggregate compensation provision did not injure plaintiffs, and that they lacked standing to attack it. Moreover, because the NCAA committed rights exclusively to the contracting networks, it was necessary to provide minimum aggregate compensation for all rights. ${ }^{42}$

The NCAA argued under the rule of reason that the legality of its television plan and network contracts was shown by their overall procompetitive effect. The principal controls-limitations on team appearances and number of broadcasts in a seasonbenefited collegiate football in competition with alternative products. Other restraints, such as restrictions on sponsors,

41 The portion of each individual game rights fee to be paid by the host institution to the visiting institution was subject to negotiation between the participating colleges. In most instances, conference rules dictated the sharing of rights fees between conference members. The University of Oklahoma, as a member of the Big Eight Conference, and the University of Georgia, as a member of the Southeastern Conference, were bound by conference sharing arrangements which were outside the ambit of NCAA regulations.

42 Moreover, plaintiffs' price-fixing claim, it was argued, offered no basis for equitable relief in any event. Future football television would occur under profoundly changed circumstances. For the first time, the NCAA contracted with two networks rather than one. Thus, it was then impossible to infer what pricing conduct would occur in the future. 
commercial time, and institutional promotional segments, benefited college football and higher education. ${ }^{43}$

These procompetitive benefits were possible through the NCAA's "packaging" of college football broadcasts. In a free market only two results, both detrimental to NCAA collegiate football, are possible. Either television is oversaturated and no product effectively marketed, or a few superpowers dominate less powerful colleges. The NCAA argued that its policies broadened football's entertainment value through greater variety and more balanced, competitive games. The athletic programs of all members were strengthened by spreading television and revenue opportunities fairly; the distribution of revenue prevented domination by prominent institutions.

These procompetitive effects, explained the NCAA, should be measured in a relevant product market that included all television programming. Within that market, the NCAA's restraints were not anticompetitive, but enhanced the variety and quality of college football programming.

\section{Lower court opinions}

The district court was not convinced by the NCAA's argument. ${ }^{4}$ It found for the plaintiff on theories of monopolization,

43 The NCAA argued that it had gradually relaxed football television controls, so that college football had become more competitive on television while still maintaining its athletic and economic benefits. The number of team appearances permitted per season had been increased, and the total exposure of games had been expanded. The NCAA also had instituted a supplementary series of broadcasts distributed for presentation on cable television for colleges not appearing frequently on the network series. The success of the NCAA's efforts to promote collegiate football as a competitive product for television was apparent to all, it contended: televising of college football thrived, net revenues to the NCAA membership increased dramatically, and the alleged adverse impact of television on live gate attendance was curtailed.

44 Indeed, the district judge was rather scathing in his criticism of the NCAA's conduct: "It is regrettable that an organization such as 
boycott, and cartelization, ${ }^{45}$ and enjoined the NCAA from prohibiting its members from negotiating separate television contracts. ${ }^{46}$ The court rejected the notion "that college football or indeed higher education itself, is not a business." 47 It determined that college football schools maximize revenue and cut costs, while maintaining high-quality competition to keep their product attractive..$^{43}$ It also rejected the gate attendance argument. The NCAA studies were more than two decades old ${ }^{49}$ and had been conducted in a controlled market. ${ }^{50}$ Additionally, the studies demonstrated an inadequate causal relationship between the decline in gate attendance and televised college football. ${ }^{51}$ The

NCAA, which has served many purposes over the years, should be found to be in violation of the laws of the United States. The Court would only observe that the wound which has today been suffered by NCAA is a self-inflicted wound. NCAA has strayed far from the purposes for which it was organized." The court then raised an extremely provocative question. "The court does not know and need not determine whether the NCAA administration, in formulating the controls at issue, was motivated by genuine concern for NCAA members, by a lust for power or by rank greed." 546 F. Supp. at 1328 .

45 Id. at $1325-28$.

$46 \quad I d$. at 1328.

47 Id. at 1288. The court went on to state that colleges are competing for students, faculty, government grants, and philanthropic support. It closed out the argument by observing: "The objectives and the past achievements of our institutions of higher learning have earned them great praise and exalted position in our social fabric. Nonetheless, it is a business and a business operated by professionals." Id.

48 Id.

49 The judge stated that it "strains logic past the breaking point" to assert that studies conducted 25 years before are still viable. Id. at 1295.

50 The court stated that it simply did not know the effects of uncontrolled television on gate attendance. $I d$.

51 The court noted, for instance, that during the years of the study, gate attendance had indeed dropped when television expanded. However, it also noted that college enrollment had likewise dropped, raising at least the possibility that one major source of attendance, college 
NCAA's plan did not limit college football to protect gate attendance; on many Saturdays there were nine hours of televised college football. ${ }^{52}$

As for protecting competition on the playing field, the NCAA's regulation of scholarships and recruitment promoted parity, rather than regulating televised college football. ${ }^{53}$ The NCAA's argument that increased revenues would create a "power elite" was not convincing because increased revenue was limited to college sports programs, ${ }^{54}$ and a "power elite" already existed despite the contracts. ${ }^{55}$ The NCAA was really arguing that competition would destroy the market, and such a defense could not justify antitrust violations. ${ }^{56}$

In deciding the monopolization issue, the court decided the relevant market was "live college football television."

students at the various institutions, may have dropped. The court said that while the NCAA sought to minimize this concern, the studies had not taken into account a logically significant factor. Id.

$52 \quad$ Id. at 1296.

53 The court also noted that the NCAA's restrictions were more likely to reward and promote uncompetitive football performance than to promote competition. Id.

54 The court stated: "The plaintiffs will continue to play football whatever the ultimate outcome of this litigation and they will do so at a profit. But other sports currently offered at those schools will suffer." Id. at 1310 .

ss The court stated that such schools as Notre Dame, University of Alabama, University of Nebraska, Pennsylvania State University, Ohio State University, University of Michigan, and the University of Pittsburgh were firmly established in the so-called "power elite" and listed the University of Georgia and Clemson University as recent arrivalsdemonstrating that it was possible to break into the elite.

56 The judge stated that if contests became too one-sided, the market would correct the problem by forcing the networks to shift to closer games to restore their ratings. It added that if a "power elite" emerged to abuse its competitive edge, then antitrust remedies would be available to those injured.

57546 F. Supp. at 1296-97. The court noted that defining the relevant market was often the most difficult part of deciding a monopo- 
day afternoons, televised college football is free from professional football competition, the most logical substitute. ${ }^{s 8}$ Since televised college football is perishable, and interest wanes after games, it does not compete against the spectrum of programming available other times. ${ }^{59}$ The alternative programming that competing networks broadcast against college football establishes it as the market, exclusive of other entertainment. ${ }^{60}$ College football did not compete with general entertainment programs which were outside the college football television market. ${ }^{61}$ Moreover, the networks were willing to suffer net revenue losses to broadcast football, eager to condition affluent college graduates to watch their programming. ${ }^{62}$ The price networks paid hinged on the ability to attract male college graduates, making it a unique market. ${ }^{63}$

The NCAA argued that the buyers in the market were television advertisers, ${ }^{64}$ but the district court agreed with the plaintiffs

lization case. It stated that the argument was even more difficult here because, since college football on television had for so long been outside the free market, it was impossible to determine what the characteristics of the market would have been if the market were free. Hence, it admitted "the definition of a relevant market necessarily involves some guesswork."

$58 \quad$ Id. at 1282.

$59 \quad I d$.

60 The court noted that one network "went dark" when college football was being broadcast by a competitor. That is, rather than sending its affiliates any programming to compete with the football game, the network left the affiliates to fend for themselves. Essentially the network was conceding that other types of entertainment could not substitute for college football. Id. at 1297.

61 Id.

62 The court explained that it was impressed by the argument that college graduates have buying power which far exceeds their number. Id. at 1299.

$\begin{array}{ll}63 & \text { Id. at } 1300 . \\ 64 & \text { Id. at } 1298 .\end{array}$ 
that the networks were the buyers. The antitrust injury related to the exclusive contract, and the buyers of that contract were the networks. ${ }^{65}$ The sellers were the colleges playing football, ${ }^{66}$ and they were unique because only colleges produced quality amateur football. ${ }^{67}$

The court found that the NCAA monopolized college football television broadcasts, ${ }^{68}$ that the NCAA controlled virtually all college football broadcasts, ${ }^{69}$ and that the NCAA erected an insurmountable barrier to new competition by prohibiting competitive broadcasts. ${ }^{70}$ The court also found the NCAA restraints unlawful under section 1 of the Sherman Act under both per se and rule of reason analyses. Its sophisticated per se inquiry found that although current contracts technically allowed negotiations between networks, they rarely occurred, ${ }^{n}$ and that the minimum aggregate fees paid by the networks determined what each college received. ${ }^{72}$ This clearly circumvented market forces ${ }^{33}$ and, under

\section{Id.}

66 In a perfectly free market, the court observed, these schools would be competing to sell broadcast rights to their football games. It then stated: "NCAA has, by virtue of its controls over football television, literally commandeered this right by acting as exclusive bargaining agent for the sale of college football television rights." Id. at 1282.

67 High school football, the court stated, had never been broadcast on a network level and had not developed the same appeal as college football. $I d$.

68 In fact, the NCAA did not deny that if college football constituted the relevant market, then it was a monopolist.

69546 F. Supp. at 1282.

$70 \quad I d$.

71 The court found, without much discussion, that the networks "have no intention of bidding" for the rights to broadcast a particular game. Second, the court declared that when one network's offer had been turned down, the other network was in an unacceptably strong bargaining position. Id. at 1293.

72 The court found that the networks computed the amount to be paid each team by subtracting the eight percent the NCAA received 
Broadcast Music Inc. v. Columbia Broadcasting System, ${ }^{74}$ the restraint distorted free market pricing and output levels. ${ }^{75}$ The court rejected the NCAA's joint venture justification, declaring that the cooperation required for football did not extend to exclusive NCAA television contracts. ${ }^{76}$ It also rejected the justification that a per se analysis did not apply to voluntary associations, ${ }^{77}$ ruling that the NCAA was not truly voluntary, and that the Sherman Act applied in either event, ${ }^{78}$ and that the restraints were not ancillary to regulations promoting amateurism. ${ }^{79}$ The court found the NCAA's promotion of amateurism laudable, but

from its share of the proceeds and then dividing the minimum aggregate fee by the number of telecasts-with regional telecasts receiving somewhat less money than national ones.

73 As an example, the court noted that on one weekend in 1981, Oklahoma and the University of Southern California, two teams with traditionally strong football programs, played and their game was carried on more than 200 stations. Two other teams, Citadel and Appalachian State, played and their game was broadcast over four stations. Yet all four teams received the same amount of money.

74441 U.S. 1 (1979).

$75546 \mathrm{~F}$. Supp. at 1305 . This of course raises an interesting question. If one assumes that the justification for the per se rule is that judicial experience teaches that certain practices so nearly always denigrate competition that affirmative considerations of social policy dictate that they be condemned without further analysis, is not a court which seeks to discover competitive or anticompetitive effects in a policy which has been condemned as per se illegal not seeking to reinvent the wheel and hence sacrificing the policy aims of the per se rule?

76 Id. at 1306. The court distinguished the NCAA's restraints from those in Broadcast Music. It stated the Broadcast Music restraints were necessary to successfully market the product-music. The NCCA restraints, it declared, were not necessary.
$77 \quad$ Id. at 1308.
$78 \quad I d$. at 1309.
79 Id. 
did not find the restraints logical extensions of amateurism..$^{80}$ And because the NCAA's restraints isolated broadcasts from the free market, ${ }^{81}$ its monopoly power precluded this particular justification. ${ }^{82}$ Lastly, the court ruled that the NCAA was a group boycott that prohibited members from playing nonmembers on television $^{83}$ and from selling to certain buyers. ${ }^{84}$ Under the rule of reason $^{85}$ the restraints were unreasonable by their nature and character and by their circumstances and history enhanced prices. ${ }^{86}$ If designed to stimulate gate attendance, the restraints controlled prices, ${ }^{87}$ and their nature and character unreasonably

80 Moreover, the court found that there were sufficient alternative methods of proceeding which would protect the amateur status of college football. $I d$.

81 Id. at $1310-11$.

82 In summing up, the court stated: "[T]he NCAA television controls are more than mere ancillary restraints. They are much more far-reaching than necessary to accomplish the legitimate purposes of NCAA. They not only inhibit competition, they destroy it. NCAA has market power, and has employed that power to both fix prices and restrict output." Id. at 1311 .

83 The court here relied upon Radiant Burners, Inc. v. Peoples Gas \& Light Co., 364 U.S. 656 (1961). In that case, the Supreme Court held unlawful a gas company's refusal to supply gas to customers who used the plaintiff's gas burners. The burners did not have a certificate of approval from the American Gas Association. The defendant was a member of the association. It claimed that by refusing to provide gas, it was simply obeying association guidelines. The Supreme Court found the purpose of the rules was not to promote safety but to insulate other burner manufacturers from competition. $546 \mathrm{~F}$. Supp. at 1313.

84546 F. Supp. at $1312,1313$.

85 The court noted that the per se rule was developed to abrogate detailed rule of reason analysis and also recognized that its own per se examination of the facts had been fairly detailed.

$86 \quad 546$ F. Supp. at 1315.

87 Indeed, the court opined that the controls took money from more powerful schools and gave it to less powerful schools. Id. 
restricted competition by limiting the number of football broadcasts. ${ }^{88}$

The Tenth Circuit Court of Appeals affirmed the district court's price-fixing holding ${ }^{89}$ but reversed the group boycott finding. ${ }^{90}$ To the extent the NCAA $^{91}$ restricted output and raised prices, its restrictions were unlawful per se. ${ }^{92}$ The restraints facially did not make markets more competitive, and could not fit the narrow Broadcast Music exception to the per se rule. ${ }^{93}$ The restraints tended to restrict competition, ${ }^{94}$ and were not necessary to protect gate attendance. ${ }^{95}$ Total viewership, live and televised, must be considered in evaluating the restrictions. ${ }^{96}$ But argument that they might enhance total viewership was "speculative,"97 and through the restrictions less-favored products were favored over more-favored ones. ${ }^{98}$ This promotion of athletic parity was rejected as an unacceptable argument against competition because it might otherwise destroy the market. ${ }^{99}$ The defense that the

88 The court said that without controls, the networks would show fewer games but more games by the same teams.

89707 F.2d 1147, 1162 (10th Cir. 1983).

$90 \quad I d$. The decision was by a vote of $2-1$. The dissenter, Judge Barrett, stated that he would hold all the NCAA television broadcasting restrictions lawful.

91 For a discussion of naked restraints, see L. Sullivan, supra note 8 , at $192-97$.

92 For a discussion of the per se rule, see id.

93441 U.S. 1.

$94 \quad 707$ F.2d at 1153.

$95 \quad I d$. at 1154.

96 Id.

$97 \quad I d$.

98 Id.

$99 \quad I d$. 
restrictions enabled NCAA football to be marketed as a series ${ }^{100}$ was not analyzed; the restraints were held facially anticompetitive and per se illegal. ${ }^{101}$

Under the rule of reason, ${ }^{102}$ the appeals court found that the restrictions illegally concentrated the market by reducing the hundreds of vendors of college football to one-the NCAA. ${ }^{103}$ College football was found to be the relevant market since ${ }^{104}$ football advertising cost $2 \frac{1}{2}$ times other programming, ${ }^{105}$ and because other programming was dissimilar and not interchangeable. ${ }^{106}$ Even if too narrow, a broader definition would not significantly decrease market power for rule of reason purposes. ${ }^{107}$ The NCAA's market power increased the risks of cartelization. ${ }^{108}$

100 Essentially, the NCAA was arguing that it restrained intrabrand competition to promote interbrand competition. Id. at 1155 .

$101 \quad I d$.

102 Id. at 1157. The court indicated that it was undertaking this analysis because it was likely the U.S. Supreme Court would be asked to review the plan.

103 The court stated that since the broadcasts could be sold only as a package, only buyers with large financial resources would be able to buy. Similarly, buyers who wanted to broadcast football on an occasional basis rather than each weekend in the fall would also be foreclosed.

104707 F.2d at 1158.

105 As did the district court, the appeals court took notice of the high income level of college graduates who are attracted to college football.

106 The court noted that often such programming as old movies, comedies, or cartoons are broadcast opposite football.

107 The court stated that the degree of market share which is significant for rule of reason purposes is different from that needed to prove monopolization. "Therefore, any concern that the market definition may overstate power may be assuaged by attributing less significance to the market share possessed. . . . The district court found the NCAA controlled virtually 100 percent of the relevant market, televised college football." 707 F.2d at 1158-59. 
The appeals court did reverse the group boycott finding. The restrictions did not shield members from all competition, ${ }^{109}$ and because the possibility existed that expelled members could play NCAA teams on television, ${ }^{110}$ this did not constitute a naked attempt to restrain competition. ${ }^{11}$

\section{The Supreme Court decision}

The NCAA argued ${ }^{112}$ that the restraints were the product of a lawful cooperative joint venture and that its procompetitive contracts required to televise games ${ }^{13}$ made this product more competitive against other televised entertainment. ${ }^{14}$ It advanced theories that the restrictions aided competition, or were competitively neutral and not prohibited. Its first theory was thai the arrangements produced on-the-field balance making college football games more competitive, ${ }^{115}$ spreading appearances, and increasing the visibility of more colleges to potential football

109 The NCAA and the broadcasters were not in competition, the court noted. Further, there was no allegation that the broadcasters were seeking to protect themselves from competition. $I d$. at 1161 .

$110 I d$.

111 Here, the court said, it could not find the expulsion provisions unreasonable. $I d$.

112 Certiorari was granted at 104 S. Ct. 272 (1983).

113 The NCAA argued that its rules were necessary to create a product which it then furnished to television networks. Petitioner's Brief at 17, 104 S. Ct. 2948 (1984).

114 Petitioner's Brief at 15 . Of course, in making this argument, the NCAA was contradicting findings by the lower courts that there was no available entertainment on Saturday afternoons which could compete with live college football games. See supra notes 95-113 and accompanying text.

115 Petitioner's Brief at 20-21. Essentially, this was the reassertion of an argument the district court had rejected as not supported in fact or law. See supra notes 118-157 and accompanying text. 
recruits. ${ }^{116}$ Such parity in television appearances would further balance teams making games more exciting and attractive. ${ }^{117}$ It next theorized that its exclusive contracts reduced network transaction costs, increasing interbrand competition, ${ }^{118}$ and enabled a network to promote college football without competing networks free riding. ${ }^{19}$ These arrangements increased gate attendance that enhanced live game excitement, ${ }^{120}$ and aided smaller schools dependent on gate receipts without television revenues. ${ }^{121}$ It last hypothesized an absence of market power, and a properly defined market that included advertisers that could readily switch among televised entertainment. ${ }^{122}$ Since its share of a market of all

116 However, this argument ignored lower court findings that without the controls, schools that would not be selected by the networks would be able to broadcast on a regional scale and hence attract prospects from their area. See 546 F. Supp. at 1294.

117 Petitioner's Brief at 21-22.

118 Id. at 22.

119 The problem with this argument was, again, that it ignored the facts. Under the proposed contract, there were two other networks that could receive free rides from advertising of NCAA football done by any network. However, the free-rider problem need not have emerged or at least could have been minimized by the fact that the networks should have been able to promote the game they were carrying. See 546 F. Supp. at $1296-1300$.

120 Of course, the district court had noted that there were often already nine hours of college football available, so that the NCAA restrictions were not, in fact, helping protect the gates from competition. Also, it found there was no credible evidence that television inhibited gate attendance. $I d$. at 1295-96. In fact, there may be evidence to the contrary. Such attractions as the major college bowl games continue to draw large crowds despite television. This would seem to suggest that a high-quality game will draw fans regardless of whether the game is televised.

121 Petitioner's Brief at 25-26. But these schools might well obtain regional contracts that would make up for their lost gate revenue. 
televised entertainment would then be low, its practices would be lawful. ${ }^{123}$

Respondents argued that the NCAA's restrictions illegally restricted the number of televised games per se. ${ }^{124}$ This artificially inflated broadcast prices and, through restrictions on members' negotiating freedoms, further competition was significantly reduced in the only televised college sport regulated by the NCAA. ${ }^{125}$ Moreover, respondents argued that the restrictions were not practically necessary as those in Broadcast Music, ${ }^{126}$ and that income was not equalized among colleges as privileged colleges made multiple television appearances. ${ }^{127}$ Indeed, without the restraints more local games could be televised, ${ }^{128}$ and since there was no credible evidence that live attendance would then drop, ${ }^{129}$ local colleges would benefit. And since the NCAA possessed market power in the market for college football television broadcasts, the restraints should be found unlawful whether under per se or rule of reason analyses. Because the networks had no satisfactory substitute for Saturday college football, prices for college broadcast rights were inflated by the restrictions, ${ }^{130}$ and even if the

$123 \quad I d$.

124 Respondent's Brief at 10-15, 104 S. Ct. 2948 (1984).

125 Specifically, the respondents were referring to basketball, which was satisfactorily governed by market forces. Respondent's Brief at 29 .

126 Id.

127 The schools who appeared received the payments from the networks. The respondents argued that if the NCAA was interested in sharing wealth, it could simply require one school with large revenues to contribute to another school with few revenues, rather than attempting to remotely control the flow of revenues by limiting price for games and number of appearances. Id. at 27-30.

$128 I d$.

129 Id.

$130 \quad I d$. 
market were to include substitutes, the NCAA still had market power. ${ }^{131}$

The Justice Department intervened, contending that the NCAA's rules should not be evaluated under either per se or rule of reason tests, ${ }^{132}$ but at the midpoint of a "continuum" between two traditional poles ${ }^{133}$ recently adopted by the Court. ${ }^{134}$ The Justice Department favored a Broadcast Music ${ }^{135}$ two-prong inquiry to determine the legality of joint marketing arrangements: whether the challenged practice "facially appears ... to ... always or almost always tend to restrict competition and decrease output," 136 and whether it was designed not to increase effi-

$131 \quad I d$.

132 United States' Brief at 7, 104 S. Ct. 2948 (1984). "It is our submission that antitrust analysis is not restricted to these two extremes, a Per Se category that precludes an examination of actual effects and an elaborate 'full blown' category that requires precise measurement of markets and market power."

133 Under this position, the circumstances of the particular case would decide how far the court must look to determine whether a restraint was indeed unlawful. Some restraints might escape per se condemnation and yet be quickly condemned upon a cursory evaluation of their purpose or their effect on the market. In other instances, a more detailed analysis might be required. The United States' approach seems to have suggested that the record be analyzed as thoroughly as necessary for the court to conclude that the challenged restraint would inhibit competition more than it would help it.

134 See, e.g., Broadcast Music, Inc. v. CBS, 441 U.S. 1, 8 (1979); Arizona v. Maricopa County Medical Society, 457 U.S. 332 (1982).

135441 U.S. 1 (1979).

136 United States' Brief at 9. This first step sounds like the per se analysis as articulated in United States v. Northern Pacific Ry., 356 U.S. 1 (1958). "[T]here are certain arguments or practices which because of their pernicious effect on competition and lack of any redeeming virtue are conclusively presumed to be unreasonable and therefore illegal without elaborate inquiry. . . ." 356 U.S. at 5. 
ciency, ${ }^{137}$ but to limit competition. ${ }^{138}$ Further, Justice asked the Court to determine whether the joint venture could work without the challenged restraints. ${ }^{139}$ Applying its test, Justice argued that the NCAA's television controls were facially unlawful ${ }^{140}$ since they appeared to restrict output, ${ }^{141}$ without increasing the NCAA's efficiency. ${ }^{142}$

Although acknowledging that such restraints are normally illegal per se, ${ }^{143}$ the Supreme Court did not invalidate them. ${ }^{144}$ Within the context of collegiate football, "horizontal" restraints are essential to product availability, ${ }^{145}$ while the other restraints may preserve college football's character and integrity. ${ }^{146}$ But, as

137 United States' Brief at 9.

138 Rather, an efficiency justification will carry the day only if the restraint, while promoting the efficiency of the defendant, forces the rest of the market to become more competitive by passing efficiency savings to consumers. $I d$. at 10.

139 Id. at 11.

140 The United States argued that the restraints were not per se unlawful, but that they should be condemned under the analysis outlined in the brief. Id. at 12-15.

141 Id. at 15-17.

142 Id. at $17-19$.

$143104 \mathrm{~S}$. Ct. at 2960 . The Court characterized the NCAA restraints as horizontal price-fixing and output limitation and stated that they are "ordinarily condemned as illegal per se." Id.

144 Id. at 2961.

145 Id. The Court went out of its way to note that its decision was not based on a lack of familiarity with the pernicious effects of price-fixing or output restraint, or on any respect for the NCAA's historic role in the "preservation and encouragement of intercollegiate athletics." Id. at 2960.

146 Id. at 2961 . The Court specifically referred to such matters as field size, game rules, and the preservation of an "academic tradition" to accompany the sport. 
for the restrictions making the game more popular or more competitive, ${ }^{147}$ the restraints only inflated price, decreased output, ${ }^{148}$ and eliminated smaller broadcasters unable to bid on broad spectrum television rights. ${ }^{149}$ The NCAA had sufficient power in the market of televised collegiate football to generate anticompetitive effects; its rules were a "naked restraint" on price and output and an exercise of that market power. ${ }^{150}$

The Court noted that the 1950s studies showing television's adverse impact on gate attendance ${ }^{151}$ were not relevant to today's market, and would be at odds with the role of the Sherman Act in assuring that competition remains the basic American economic policy. ${ }^{152}$ While many of the NCAA rules were justified because they made the game more competitive and more attractive to broadcasters, the television restraints were not of that category. ${ }^{153}$

147 Id. at 2962.

148 The Court declared, in fact, that the coercive aspects of the plan made the market unresponsive to consumer demand-a point it found "perhaps the most significant." It is interesting to note here that the Court seems at least implicitly to be adopting the view of Professor Bork, who also argues that consumer welfare is the proper goal of antitrust law. See R. Bork, supra note 21, at 81-89.

149 The Court found that many small television broadcasters who might wish to broadcast one or two games of a locally popular team were denied this chance because only broadcasters who wished to purchase rights covering all the NCAA teams could compete effectively.

$150104 \mathrm{~S}$. Ct. at 2965 . "When there is an agreement not to compete in terms of price or output, 'no elaborate industry analysis is required'."

151 The Court made it clear it was referring to attendance at other games rather than attendance at the game that was being broadcast. Id. at 2969.

152 The Court observed that under the rule of reason, a restraint could not be justified on the ground that competition was unreasonable. Id.

153 The Court held that the television plan was "not even arguably tailored to serve such an interest." The Court noted the plan did not attempt to regulate the money a college might spend. Moreover, it stated 
Because these restraints were not classic price-fixing, or necessary adjuncts to a lawful plan, the Court invoked a test functionally indistinguishable from the rule of reason. ${ }^{154}$ It rejected the idea that without market power technical restraints should be permitted. ${ }^{\text {ss }}$ Although consistent with Chicago school theory that only market power can impair consumer wealth maximization, ${ }^{156}$ this idea was rejected because as a matter of law the lack of market power "does not justify a naked restraint," thereby rejecting consumer wealth and efficiency justifications. ${ }^{157}$ There must be procompetitive reasons offered in defense of restraints on competition. ${ }^{158}$ But here the challenged restraints were not intended to equalize competition, or neutralize a "power elite," but consti-

there was no evidence the restriction produced any more equality than would other methods. The Court agreed with the district court's finding that more games would be broadcast and more schools would receive television revenue under a free market. $I d$.

154 See source cited supra note 27.

155104 S. Ct. at 2965.

156 The lead attorney for the NCAA in the case before the Supreme Court, as noted above, was Frank Easterbrook, an adherent of the Chicago school. Id. As also noted above, the Chicago school employs a theory of market power which usually will result in a much broader and more elastic market definition and hence less market power for antitrust defendants than do the more traditional schools of thought. See, e.g., Landes \& Posner, Market Power in Antitrust Cases, 94 Harv. L. Rev. 937 (1981). The authors argue that geographic and product substitution evidence should be more freely allowed and define market power as the "ability to raise price above the competitive level without losing so many sales so rapidly that the price increase is unprofitable. . . " Hence, if a firm or group of firms acting together do not have the ability to raise prices above the competitive level (market power), then the firm's conduct cannot have a pernicious effect on consumer wealth maximization because consumers would not be forced to pay a higher price.

157 The decision thus affirms the rule that a naked restraint is unlawful even where the defendant does not have the market power or the ability to set prices at levels other than those arrived at by market forces. 
tuted an agreement that restricted output. ${ }^{159}$ The Court obviously rejected a one-dimensional antitrust approach, but the debate for one continues.

\section{The Chicago school's limits on antitrust}

Is antitrust an "imperfect" tool for the regulation of competition? ${ }^{160}$ Is antitrust's proper goal the increase of economic efficiency? ${ }^{161}$ Are traditional antitrust methods effective? ${ }^{162}$ Should categories of per se restraints shrink? ${ }^{163}$ Does the rule of reason lack content? ${ }^{164}$ Are efforts to provide content "snipe hunts"? 165 Sophisticated business operations require cooperation, ${ }^{166}$ and antitrust must weigh social policies, ${ }^{167}$ but do its enforcement costs outweigh its benefits? ${ }^{168}$ If antitrust costs are the loss of beneficial

\footnotetext{
$159 \quad I d$. at 2970.

160 Easterbrook, supra note 28, at 39.

161 Id. at 14-16.

162 Id. at 9-10.

163 "We see competitive benefits in practices that once were thought to be uniformly pernicious." Easterbrook states that the Supreme Court has removed tying arrangements from the per se category "in all but name." In addition, he states the Court has "stood by" while the lower courts have abrogated the per se rule in regard to boycotts. Id. at 10 .
}

164 Easterbrook argues that judges and juries are incapable of determining accurately whether an agreement helps or hinders competition. Id. at 5-6.
$165 \quad$ Id. at 13.
166 Id. at 1.
$167 \quad I d$. at 3.

168 "There are good theoretical reasons to believe that the costs of (some antitrust) enforcement efforts have exceeded the benefits . . . antitrust is costly. The judges act with imperfect information about the effects of practices at stake. The costs of action and information are the limits of antitrust." Id. at 4. 
business practices, ${ }^{169}$ society loses efficiencies, but if only efficiency determines antitrust results, the law will lose greater competitive justifications. ${ }^{170}$

A more relaxed antitrust scheme not only will allow "socially undesirable" behavior through error, ${ }^{171}$ but also will allow cooperation that produces market power that may not be self-correctable. Judge Easterbrook has produced a series of presumptions to filter efficiency-enhancing arrangements. ${ }^{122}$ Filters highlight actual competitive effects, as the first concentrates on market power ${ }^{173}$ and ignores restraints unless imposed with the market power ${ }^{174}$ to raise prices above competitive levels that will harm consumers. ${ }^{175}$ Easterbrook's filters are a "quick, painless and correct end to litigation" 176 that stimulate market entry, ${ }^{177}$ and will not invalidate such cooperative ventures as joint advertising that absent market power ${ }^{178}$ cannot reduce consumer welfare.

169 He states that often a business practice will be successful and efficient without the businessman being able to explain why it is procompetitive. Once pro-efficiency explanations have been developed, the practice has often been eliminated because of court action. Id. at 6-7.

$170 \quad I d$. at 8-9.

171 "The per-se rule condemns whole categories of practices even though some practices in these categories are beneficial. The court permits such overbreadth because all rules are imprecise. . . " Id. at 15.

172 Id. at 17.

173 "Market power is the ability to raise price significantly without losing so many sales that the increase is unprofitable." Id. at 20.

174 Id.

175 "When there is no market power, the market is better than the judicial process in discriminating the beneficial from the detrimental." Id. at 21 .

176 Id. at 23.

177 Id. at $21-22$.

178 Id. at 21. See United States v. Sealy, Inc., 388 U.S. 350 (1967); United States v. Topco Assocs., 405 U.S. 596 (1972). 
Easterbrook's second filter rejects claims not relatable to a defendant's increased profit. ${ }^{179}$ If not profitable, a defendant will stop business losses before antitrust proscribes its conduct. ${ }^{180}$ If unprofitable restraints persist, because a market does not "perfectly penalize" misconduct, markets still "do so better than the next best alternative" 181 and antitrust impositions should be resisted.

The next filter operates if a restraint survives the first two "threshold" tests, and has potential competitive benefits. ${ }^{182}$ Naked restraints will have already been condemned, ${ }^{183}$ and "obviously harmless" practices will have been identified. However, the potential effects of partial integration, ${ }^{184}$ including tying, restricted dealing, and other vertical restraints, will be analyzed through this filter. ${ }^{185}$ And if other firms in the market have not adopted the restraint under examination, ${ }^{186}$ the case should be dismissed. "Potentially anticompetitive outcomes" require multiple adoption by competitors before they will destroy competition. ${ }^{187}$

\section{Easterbrook, supra note 28, at 24.}

180 "The market brings home to the offender any losses it imposes on others-and it brings them home more quickly than courts do. . . . The sanction imposed by the business losses will clear up the practice in due course." Id.

181 He states that this is consistent with "the entire corpus of antitrust doctrine" which states that competitive markets do better than judges or regulators in rewarding practices that create economic benefit and penalizing others. $I d$.

$182 I d$. at 29.

$183 I d$. at 30 . They obviously have no procompetitive potential.

184 Id.

185 Id.

$186 I d$.

187 Id. An example given is that if Sony uses a resale price maintenance agreement for its televisions and General Electric does not, dealers who want to cheat on the cartel can do so by cutting the prices of the G.E. sets. 
The fourth filter focuses on product demand and whether it rises or falls after the restraint's adoption. If demand rises, the benefits of the restraint exceed its costs, but if it falls, the restraint has a negative impact. Also, if a restraint is inefficient, latent competition will challenge the practice. ${ }^{188}$ Thus a firm engaging in a practice for five years without losing market share has not restrained trade illegally. ${ }^{199}$ If entry barriers are especially low, then the number of years could be reduced. ${ }^{190} \mathrm{~A}$ five-year cushion might not have been intended by Easterbrook, but such a period constructively immunizes a particular practice from antitrust enforcement while other, possibly more beneficial practices are not.

Finally, Easterbrook questions whether a business rival should be permitted to bring a suit that drives up a competitor's costs, ${ }^{191}$ and proposes that a line be drawn between suits initiated by competitors and those by consumers. Competitors will likely inflict harm to protect their own inefficiencies, ${ }^{192}$ but their tactic will elevate their own prices and drive customers to competitors, or entice rivals to sell at lower prices through their greater skill. In the first case, competition is helped, not harmed; in the second case, there is no basis for antitrust enforcement. ${ }^{193}$ Predatory prices may injure rivals initially, but the market will self-correct high monopoly prices. ${ }^{194}$

188 Id. at 32.

$189 I d$. at 33. He states that five years is arbitrary. The factors should include "entry hurdles" (costs not recoverable if entry is abandoned), and entry lag ("the length of time entry takes even if there are low hurdles and no barriers").
190 Id.
191 Id.
192 Id. at 34.
193 Id. at 36.
194 Id. at 37. 
The filter theory promotes the Chicago school's concept of economic efficiency, one that rejects competition as rivalry. ${ }^{195}$ Since inefficient practices are market-corrected automatically, efficient conduct must not be condemned, nor must society waste resources on antitrust enforcement. Only competitors offering consumers better deals ${ }^{196}$ will survive the market; perhaps survival correlates the filters with economic efficiency most clearly. If a practice survives, it must serve consumer wealth maximization, ${ }^{197}$ and must be efficient.

The filter theory raises philosophical and pragmatic difficulties. Its narrow ideology rejects rivalry for fostering social disintegration. ${ }^{198}$ But in the specific instance of rivalry as a goal of the Federal Communications Commission, the broadcast industry has not disintegrated. Whether the goal is rivalry or diversity, a coherent antitrust policy will result. Efficiency can be combined with other goals, ${ }^{199}$ as in $N C A A$, to balance policy. ${ }^{200}$

That efficiency was not intended by Congress as the sole antitrust goal is obvious. ${ }^{201}$ As expressed in Brown Shoe Co. $v$.

195 "[C]ompetition cannot be defined as the state of maximum rivalry, for that is a formula of disintegration."

196 Id. at $29-30$.

197 Id. at 31-32.

$198 \quad I d$. at 13.

199 See Hovenkamp, Distributive Justice and the Antitrust Laws, 51 Geo. Wash. L. Rev. 1 (1982); Schwartz, "Justice" and Other Non Economic Goals of Antitrust, 127 U. PA. L. Rev. 1076 (1979).

200 See H. Hovenkamp, Economics and Federal Antitrust Law 42 (1984). "All these alternative goals can be inconsistent with the goal of maximizing allocative efficiency. In addition, many are inconsistent with each other. If courts adopt any mixture of goals, antitrust is likely to be guided by conflicting policies which must then be balanced against each other. To be sure, this is not a unique phenomenon."

201 See supra notes 7-12 and accompanying text. 
United States, ${ }^{202}$ legislative history displays Congress' fear of "a rising tide of economic concentration in the American economy." ${ }^{203}$ Here is clearly expressed a major competing goal, one that does not preclude an antitrust role for actual efficiencies, but does preclude the speculation of final efficient results.

In the $N C A A$ case, efficiency was acknowledged, ${ }^{204}$ but speculative and logically weak efficiency arguments did not prevail over a clearly expressed intent to restrict the plaintiffs' economic and market freedoms. Lack of market power is no reason to allow contracts or conspiracies that restrain trade. Markets cannot be defined definitively; defendants may argue for a broad television entertainment market, ${ }^{205}$ while the Court can narrowly define televised college football as the market. ${ }^{206}$ Markets through the breadth of their definition can protect restraints, making consistent policy difficult and business planning impossible. But even without market power, economic freedom can be restrained. Assuming the NCAA did not have market power, small broadcasters could still not televise selected games, foreclosed not by market forces but by the restraints. Local football teams were shut out of television; national teams were denied all the television revenue their abilities merited.

Moreover, restraints unrelated to profits should not be validated. Measuring a restraint's profit contribution is virtually inpossible; a profit or loss can be attributed to production, marketing, or random economic events. If the television restraints did not profit the NCAA, the decision did not harm efficiency.

202370 U.S. 294, 315 (1961) (challenge to a merger of two corporations; case brought under Clayton Act).

203 Id.

$204104 \mathrm{~S}$. Ct. at 2960-61.

205 Petitioner's Brief at 33-36.

206104 S. Ct. at 2966. 
Minimally competitive markets will not penalize restraints as Easterbrook suggests, ${ }^{207}$ but restraints themselves will weaken markets. If the NCAA could forbid the University of Oklahoma from signing a network television contract unilaterally, the network would sign another team, but not last year's NCAA champion. Not every network need acquiesce before a university is harmed substantially. Consumer behavior is not one-dimensional, and product demand may increase in spite of a restraint. Quality refinements, marketing programs, or competitive behavior may overcome a restraint's negative impact. Was the increase in NCAA football television audiences due to the restraint, to a more affluent society that could afford television and more leisure, to an increase in college graduates cheering their alma mater, or to technological advances making games more exciting?

Should each restraint have a probationary period of five years? Even a short-lived inefficient restraint might cause great harm, but only if challenged initially would it be invalidated. The NCAA's restraints weren't challenged for five years, and not before potential television revenues were denied meritorious colleges.

Efficiencies that reduce prices are not always attacked by rivals. If so, defendants can countersue, or courts can award attorneys' fees to thwart frivolous claims. But consumers do not have the knowledge to mount antitrust attacks; only competitors have access to the kind of information and the quantum of resources necessary to pursue antitrust remedies. Television viewers could not sue without knowledge of the NCAA contracts, and could not without the resources. And, some advertisers may have preferred the restraints for their ready access to monopolized audiences. Only colleges eager to compete for viewers had reason to sue, and had the resources.

In summary, efficiency is an important antitrust consideration, but theoretical arguments that interfere with economic freedom are not. If coercive in intent or purpose, any restraint on economic liberty that restricts output through cooperation cannot

Easterbrook, supra note 28, at 23-25. 
be justified, and in NCAA the defendants' arguments about efficient output restriction were denied. Efficiency is not the only goal of antitrust, but one of several competing goals. The Supreme Court has dealt the Chicago school its most solid body block since Jay Brinswanger's days.

\section{Conclusion}

Alternative approaches to competition, as well as antitrust's proper goals, have political underpinnings. One approach sees competition synonymous with efficiency and consumer wealth maximization through cooperation and economic integration. ${ }^{208} \mathrm{~A}$ new "filter" approach defers to the laissez-faire values of a minimal government, ${ }^{209}$ while others see competition embracing several economic and political goals. Values like economic opportunity and the prevention of economic coercion are equally important goals, and government policing of free markets is necessary to counterbalance the power of private capital. ${ }^{210}$ The $N C A A$ case establishes the Supreme Court's evaluation of efficiency, that it will measure efficiencies against coercive intent and effect, and will not permit trade to be restrained even if efficient in the short term. ${ }^{211}$

208 See supra note 9 and accompanying text.

209 See Easterbrook, supra note 28.

210 See supra notes 11-12 and accompanying text.

211 See supra notes 35-157 and accompanying text. 